
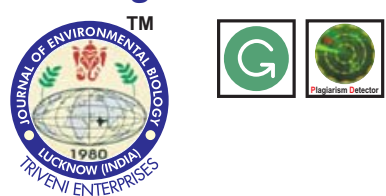

\title{
Effect of vermicompost on greengram productivity and soil health under hilly ecosystem of North East India
}

Authors Info

D.J. Rajkhowa* , A.K. Sarma', K. Mahanta ${ }^{3}$, U.S. Saikia ${ }^{1}$ and Krishnappa R. ${ }^{2}$

'Division of Natural Resource Management, ICAR Research Complex for NEH Region, Umiam-793 103, India

${ }^{2}$ Division of Crop Production, ICAR Research Complex for NEH Region, Umiam-793 103, India

${ }^{3}$ Department of Agronomy, Assam Agricultural University, Jorhat-785 013, India

${ }^{*}$ Corresponding Author Email : djrajkhowa@gmail.com

\section{Key words}

Available nutrients, Greengram, Microbial population, Soil health, Vermicompost

Publication Info

Paper received : 10.07 .2015

Revised received : 20.03.2016

Accepted:06.06.2016

\section{Abstract}

Aim: The study aimed at evaluating of an appropriate nutrient management practice for increasing greengram productivity, improving soil health, and thus bringing sustainability to pulse production system in the hilly terrains of North East India.

Methodology: A field experiment was conducted during 2013 and 2014 to evaluate the effect of vermicompost, Rhizobium and lime in different combination with fertilizers on greengram productivity and soil health under terrace land situation of Meghalaya. Treatments comprised of recommended dose of fertilizer (RDF), 50\% RDF + Rhizobium, 50\% RDF + Rhizobium + lime $4 \mathrm{q}$ ha ${ }^{-1}, 50 \%$ RDF + Vermicompost (VC) 2.5 tha ${ }^{-1}, 50 \%$ RDF + lime 4 q ha-1 and $50 \%$ RDF + VC 2.5 tha $^{-1}+$ lime $4 q_{\text { ha }}{ }^{-1}$.

Results: Nutrient management practices significantly influenced the yield components, yield, soil nutrient status, as well as microbial population in soils. Integrated use of $50 \%$ RDF + VC $2.5 \mathrm{t} \mathrm{ha}^{-1}+\operatorname{lime} 4 \mathrm{q} \mathrm{ha}{ }^{-1}$ resulted in significantly higher yield of greengram ( $\left.10 \mathrm{q} \mathrm{ha}{ }^{-1}\right)$ and improved the soil organic carbon (2.5\%), bacterial and fungal population, $\mathrm{pH}$ and available $\mathrm{N}, \mathrm{P}_{2} \mathrm{O}_{5}$ and $\mathrm{K}_{2} \mathrm{O}$ compared to recommended dose of fertilizer applied alone.

Interpretation: The results of the study indicated that the integrated use of $50 \%$ RDF with vermicompost 2.5 tha $^{-1}$ and lime $4 \mathrm{q} \mathrm{ha}^{-1}$ is profitable for enhancing greengram productivity and improving soil health under hilly ecosystem of North East India.

\section{GREENGRAM PRODUCTION IN} HILL ECOSYSTEM

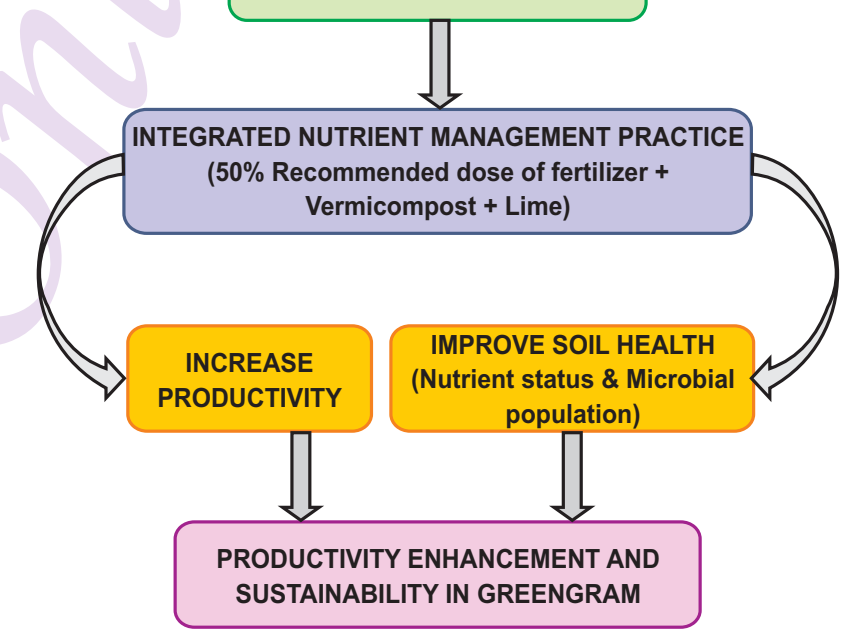




\section{Introduction}

Farming in north east hill region of India is highly complex, diverse and risk prone. Productivity of most of the crops in this region is low due to a number of constraints; of which lack of appropriate nutrient management is one of the major constraints (Rajkhowa and Manoj-Kumar, 2013). Undulating topography, faulty land use system (general practice of shifting cultivation in the hill slopes), soil erosion, soil acidity, poor nutrient status of soil, low moisture retention capacity etc. are some of the inherent problems of the region limiting crop productivity. The available $\mathrm{N}$ and $\mathrm{K}$ status of soil falls under low to medium range while available $P$ in the soil is in low range. Fertilizer consumption in the region is very poor (average $20 \mathrm{~kg} \mathrm{ha}^{-1}$ ) against the national average consumption of $133.2 \mathrm{~kg} \mathrm{ha}^{-1}$ (Indian Fertilizer Scenario, 2010). The farmers of the north east hill region generally cultivate cereal crops like rice, maize and seasonal vegetables. The region is deficit in pulse production (81.7\%), and the poor productivity of pulse in the region is mainly attributed to their cultivation in poor and marginal soil with improper nutrient management. Oflate, greengram cultivation is gaining popularity in the region, however in order to enhance its productivity evaluation of appropriate nutrient management practices is important. Farmers are often constraint in applying recommended dose of fertilizer owing to their poor economic conditions and lack of timely availability. Hence, there is a urgent need for the evaluation of appropriate nutrient management practices for enhancing greengram productivity. Integrated use of fertilizer with various organic sources is reported to sustain higher crop productivity, soil quality, as well as soil productivity (Kusro et al., 2014; Swarup and Wanjari, 2000; Singh et al., 1998). The decline in soil organic matter due to lack of recycling enough crop or animal residues, coupled with insufficient nutrient applications often led to impaired soil health and declining factor productivity. The effect of physical and chemical degradation of soils are quite obvious, but biological degradation due to loss of specific soil organic matter fractions and the 'autochthonous microbial communities' dependent upon them is insidious (Rao, 2007). Escalating fertilizer cost, growing environmental concerns and need for long term maintenance of soil health, necessitates the development of integrated nutrient management practice(s) for sustaining crop productivity and improving soil health. Of late, production and use of vermicompost for enhancing crop productivity and improving soil health is gaining popularity among the farming community. The possibility of utilizing different plant biomass (weed biomass, crop residue etc.) into quality organic manure was earlier reported by Mahanta et al. (2014). Improvement in soil health and crop productivity, following vermicompost application, have been earlier reported by many workers (Karmakar et al., 2013; Rajkhowa et al., 2003; Rajkhowa et al., 2000). Vermicompost enhances soil biodiversity by promoting beneficial microbes, which in turn enhances plant growth directly by production of plant growth regulating substances (hormones and enzymes) and indirectly by controlling plant pathogens, nematodes and other pests, thereby enhancing plant health and minimizing the yield loss (Pathama and Sakthivel, 2012). Vermicompost is also reported to contain plant nutrients in the readily available form (Edwards and Burrows, 1988) and the presence of biologically active substance such as plant growth regulators. (Tomati et al., 1987). Sinha et al. (2009) and Makulec (2002) reported that vermicompost can significantly influence the growth and productivity of plants due to their micro and macro elements, vitamins, enzymes, hormones etc. In cognizance of the above, this study was undertaken to develop an appropriate nutrient management practice for increasing greengram productivity, improving soil health and there by, bringing sustainability to pulse production system in the hilly terrains of North East India.

\section{Materials and Methods}

Field experiments were conducted during 2013 and 2014 under terrace land situation at Umiam, Meghalaya, India. Geographically, the area is situated at northern latitude $25^{\circ} 41^{\prime}$ and eastern longitude $91^{\circ} 55^{\prime}$ at an altitude of 3251 feet (990.9 m) above mean sea level (msl). The soil of the experimental field was acidic (pH: 4.8) containing $2.0 \%$ organic carbon, $268,14.6$ and $115 \mathrm{~kg} \mathrm{ha}^{-1}$ of $\mathrm{N}, \mathrm{P}_{2} \mathrm{O}_{5}$ and $\mathrm{K}_{2} \mathrm{O}$, respectively. The initial fungal and bacterial population in soil was $18 \times 10^{5} \mathrm{~g}^{-1}$ and $154 \times 10^{6} \mathrm{~g}^{-1}$ soil, respectively. Treatments comprised of recommended dose of fertilizer (RDF) i.e., 20-60-40 kg ha ${ }^{-1}$ of $\mathrm{N}, \mathrm{P}_{2} \mathrm{O}_{5}$ and $\mathrm{K}_{2} \mathrm{O}, 50 \%$ RDF + Rhizobium, 50 \% RDF + Rhizobium + lime $4 \mathrm{q} \mathrm{ha}^{-1}, 50 \%$ RDF + vermicompost (VC) 2.5 t ha $^{-1}, 50 \%$ RDF + lime $4 \mathrm{q} \mathrm{ha}^{-1}$ and $50 \%$ RDF + VC $2.5 \mathrm{t} \mathrm{ha}^{-1}+$ lime $4 \mathrm{q} \mathrm{ha}^{-1}$. Fertilizers as per treatment were applied in the form of urea, single super phosphate (SSP) and muriate of potash (MOP). Vermicompost used in the study contained $1.9 \% \mathrm{~N}, 1.2 \% \mathrm{P}$ and $1.6 \% \mathrm{~K}$ with $\mathrm{C}: \mathrm{N}$ ratio of 15:1. Lime @ $4 \mathrm{q}$ ha ${ }^{-1}$ was applied in rows as per treatment and incorporated manually in soil before sowing. Greengram was sown in rows $20 \mathrm{~cm}$ apart. The treatments were arranged in a randomized block design with four replications. The crop was sown in the month of September and harvested in December during both the years. The yield and yield components were recorded at harvest.

Soil samples were collected from each plot $(0-20 \mathrm{~cm}$ depth), air dried in laboratory, sieved through $2 \mathrm{~mm}$ sieve, and analyzed for $\mathrm{pH}$, organic carbon, available $\mathrm{N}, \mathrm{P}$, and $\mathrm{K}$. Soil $\mathrm{pH}$ (1:2.5 soil/water) was measured using a glass electrode. Soil organic carbon (SOC) was determined by the wet digestion method (Walkley and Black, 1934), Available N (potentially mineralizable $\mathrm{N}$ ) was estimated by alkaline $\mathrm{KMnO}_{4}$ distillation method (Subbiah and Asija, 1956), available P by the Bray-I method (Bray and Kurtz, 1945), and available K by ammonium acetate extraction followed by emission spectrometry (Jackson, 1962).

Fungal and bacterial population in soil $(0-20 \mathrm{~cm}$ depth) were determined by serial dilution technique on Potato Dextrose 


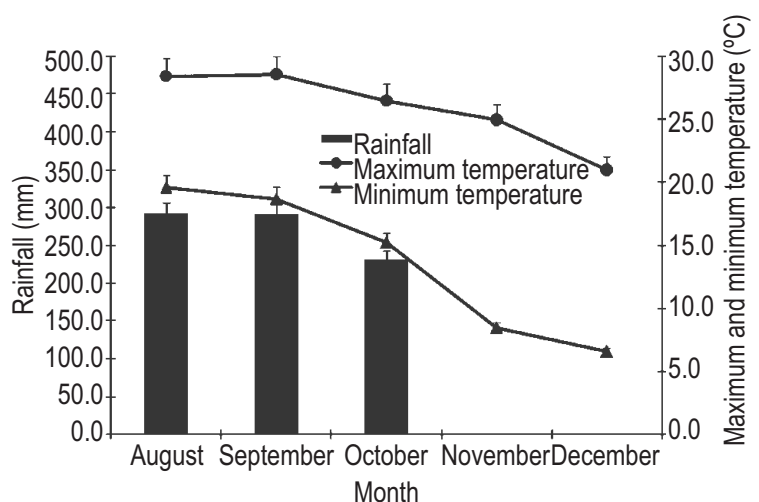

Fig. 1 : Mean maximum and minimum temperature $\left({ }^{\circ} \mathrm{C}\right)$ and rainfall $(\mathrm{mm})$ of the study area during the year 2013 (August-December)

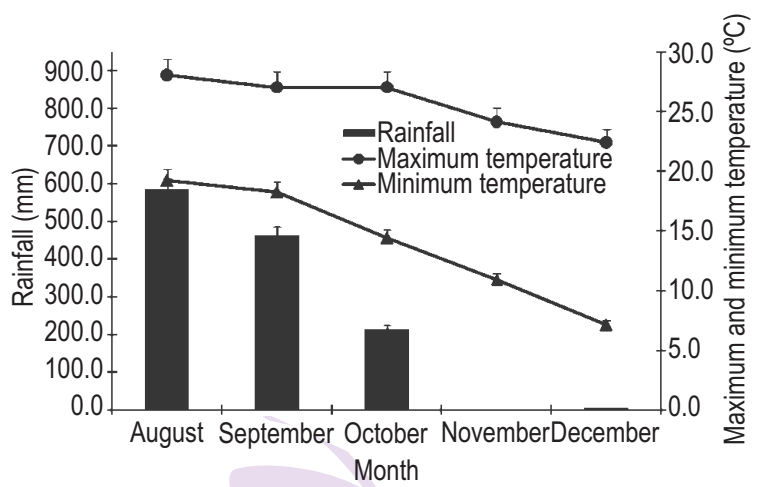

Fig. 2 : Mean maximum and minimum temperature $\left({ }^{\circ} \mathrm{C}\right)$ and rainfall $(\mathrm{mm})$ of the study area during the year 2014 (August-December)

Table 1 : Effect of nutrient management on yield and yield attributes of greengram (Pooled data of 2013 and 2014)

\begin{tabular}{|c|c|c|c|c|c|c|c|}
\hline Treatment & Pod plant ${ }^{-1}$ & $\begin{array}{l}\text { Pod length } \\
\text { (cm) }\end{array}$ & Seed pod ${ }^{-1}$ & $\begin{array}{l}\text { Root weight } \\
\text { (g plant }^{-1} \text { ) }\end{array}$ & $\begin{array}{l}\text { Seed yield } \\
\left(q h^{-1}\right)\end{array}$ & $\begin{array}{l}\text { Stover yield } \\
\left(q \mathrm{ha}^{-1}\right)\end{array}$ & $\begin{array}{l}100 \text { seed weight } \\
\text { (g) }\end{array}$ \\
\hline $\begin{array}{l}\text { Recommended dose of } \\
\text { fertilizer (RDF) }\end{array}$ & $14.0^{\mathrm{ab}} \pm 1.7$ & $5.1^{\mathrm{a}} \pm 0.98$ & $6.0^{b} \pm 0.58$ & $0.44^{d} \pm 0.35$ & $9.2^{b} \pm 0.81$ & $14.3^{b} \pm 0.87$ & $4.2^{\mathrm{a}} \pm 0.46$ \\
\hline $50 \%$ RDF+ Rhizobium & $11.3^{\mathrm{ab}} \pm 1.6$ & $4.4^{\mathrm{ab}} \pm 0.52$ & $5.7^{\circ} \pm 0.64$ & $0.49^{c} \pm 0.34$ & $8.1^{\mathrm{c}} \pm 0.75$ & $11.5^{c} \pm 0.87$ & $3.8^{d} \pm 0.23$ \\
\hline $\begin{array}{l}50 \% \text { RDF+ Rhizobium+ } \\
\text { Lime } 4 \text { q ha }^{-1}\end{array}$ & $11.6^{\mathrm{ab}} \pm 1.5$ & $3.5^{\mathrm{b}} \pm 0.75$ & $5.7^{\circ} \pm 0.35$ & $0.50^{\circ} \pm 0.52$ & $8.0^{\text {cd }} \pm 0.87$ & $13.9^{b} \pm 0.64$ & $4.1^{\mathrm{ab}} \pm 0.81$ \\
\hline $50 \%$ RDF+ VC 2.5 tha $^{-1}$ & $12.3^{\mathrm{ab}} \pm 1.7$ & $4.3^{\mathrm{ab}} \pm 0.46$ & $5.0^{d} \pm 0.57$ & $0.54^{b} \pm 0.40$ & $7.9^{d} \pm 0.12$ & $8.6^{d} \pm 0.69$ & $4.0^{\mathrm{bc}} \pm 0.23$ \\
\hline $50 \%$ RDF+ Lime $4 q^{~ h a-1}$ & $9.0^{b} \pm 1.4$ & $3.9^{b} \pm 0.40$ & $5.0^{\mathrm{d}} \pm 0.63$ & $0.49^{c} \pm 0.23$ & $5.9^{\mathrm{e}} \pm 0.23$ & $8.9^{d} \pm 0.75$ & $3.9^{\text {cd }} \pm 0.29$ \\
\hline $50 \%$ RDF+VC 2.5 tha $^{-1}+$ & $19.3^{\mathrm{a}} \pm 1.6$ & $3.7^{\mathrm{b}} \pm 0.40$ & $6.7^{\mathrm{a}} \pm 0.52$ & $0.58^{\mathrm{a}} \pm 0.40$ & $10.0^{\mathrm{a}} \pm 1.4$ & $19.8^{\mathrm{a}} \pm 0.98$ & $4.1^{\mathrm{ab}} \pm 0.69$ \\
\hline Lime $4 \mathrm{qha}^{-1}$ & & & & & & & \\
\hline
\end{tabular}

Values within the same column followed by different letters $(a, b, c, d, e)$ are significantly different from each other at 0.05 level by Duncan Multiple Range Test(DMRT)

Agar (PDA) and Nutrient Agar Media (NAM), respectively. In this technique, a soil suspension was prepared by adding $1.0 \mathrm{~g}$ soil to $10 \mathrm{ml}$ sterile distilled water and vortexed well for $15 \mathrm{~min}$. Each suspension was serially diluted $10^{-1}$ to $10^{-6}$. Briefly, $0.1 \mathrm{ml}$ of $10^{-5}$ (for fungi) and $10^{-6}$ (for bacteria) dilution was pipette onto the Petri plate containing PDA and NAM respectively, spread with a glass spreader and incubated at $28^{\circ} \mathrm{C}$ for fungal and $37^{\circ} \mathrm{C}$ for bacterial observation. Each colony that appeared on the plate was considered as one colony forming unit (CFU) (Waksman, 1927; Nazir, 2007). The number of CFU formed in the Petri plate was multiplied by reciprocal of dilution factor to determine the number of population per gram of soil.

\section{Results and Discussion}

Different meteorological variables viz. rainfall, maximum and minimum temperature of the study area during 2013 and 2014 in the cropping period (August- December) have been presented in Fig. 1 and Fig. 2 respectively. The total rainfall received during the period was $815.2 \mathrm{~mm}$ and $1264.3 \mathrm{~mm}$. The maximum temperature during the study period ranged from 21.0- $28.6^{\circ} \mathrm{C}$ and $22.4-28.0^{\circ} \mathrm{C}$, whereas minimum temperature ranged from 6.6- $19.6^{\circ} \mathrm{C}$ and $7.1-19.2^{\circ} \mathrm{C}$, respectively. As such the crop did not suffer from moisture stress condition.

The nutrient management practices significantly influenced the yield and yield attributing components of the crop (Table 1). Number of pods per plant and seed per pod ranged from 9-19.3 and 5-6.7 and were significantly higher with the treatment receiving $50 \%$ RDF + VC 2.5 tha $^{-1}+$ lime $4 \mathrm{q} \mathrm{ha}^{-1}$. Test weight (100 seed weight) ranged from $3.8-4.2 \mathrm{~g}$, highest being with recommended dose of fertilizer and was at par with the treatments involving 50\% RDF + VC 2.5 tha ${ }^{-1}+$ lime $4 \mathrm{q} \mathrm{ha}^{-1}$. Integrated use of $50 \%$ RDF + VC 2.5 t ha $^{-1}+$ lime $4 \mathrm{q} \mathrm{ha}^{-1}$ resulted in significantly higher seed and stover yield of greengram followed by the treatment receiving RDF alone. The increase in seed yield might be due to improvement in yield components following integrated nutrient management practices. Increased and prolonged availability of nutrients, improvement in soil physical properties, as well as biological activity due to use of vermicompost might have resulted in increased plant growth, yield components and yield. Further improvement in soil $\mathrm{pH}$ following the application of 
Table 2 : Effect of nutrient management on soil nutrient status and microbial population (Pooled data of 2013 and 2014)

\begin{tabular}{|c|c|c|c|c|c|c|c|}
\hline \multirow[t]{2}{*}{ Treatment } & \multirow[t]{2}{*}{$\mathrm{pH}$} & \multicolumn{3}{|c|}{ Nutrient (kg ha $\left.{ }^{-1}\right)$} & \multirow{2}{*}{$\begin{array}{l}\text { Soil organic } \\
\text { carbon }(\%)\end{array}$} & \multirow{2}{*}{$\begin{array}{l}\text { Bacterial } \\
\text { population } \\
\left(\mathrm{CFU} \times 10^{6} \mathrm{~g}^{-1}\right)\end{array}$} & \multirow{2}{*}{$\begin{array}{l}\text { Fungal } \\
\text { population } \\
\left(\mathrm{CFU} \times 10^{5} \mathrm{~g}^{-1}\right)\end{array}$} \\
\hline & & $\mathrm{N}$ & $\mathrm{P}_{2} \mathrm{O}_{5}$ & $\mathrm{~K}_{2} \mathrm{O}$ & & & \\
\hline $\begin{array}{l}\text { Recommended dose of } \\
\text { fertilizer (RDF) }\end{array}$ & $4.73^{\mathrm{bc}} \pm 0.27$ & $275.9^{c} \pm 3.2$ & $20.8^{b} \pm 1.4$ & $121.9^{c} \pm 0.75$ & $2.2^{b} \pm 0.29$ & $177.0^{\mathrm{d}} \pm 2.0$ & $20.3^{d} \pm 1.2$ \\
\hline $50 \%$ RDF+ Rhizobium & $4.70^{c} \pm 0.35$ & $269.7^{\mathrm{d}} \pm 2.6$ & $13.8^{\mathrm{c}} \pm 0.81$ & $112.9^{f} \pm 0.92$ & $2.1^{c} \pm 0.23$ & $222.0^{b} \pm 2.0$ & $33.7^{b} \pm 1.0$ \\
\hline $\begin{array}{l}50 \% \text { RDF+ Rhizobium+ } \\
\text { Lime } 4 \text { q ha }^{-1}\end{array}$ & $4.90^{\mathrm{ab}} \pm 0.40$ & $275.9^{c} \pm 2.1$ & $19.8^{\mathrm{b}} \pm 0.81$ & $119.4^{e} \pm 1.0$ & $2.3^{\mathrm{b}} \pm 0.17$ & $237.3^{b} \pm 1.7$ & $38.0^{b} \pm 1.3$ \\
\hline $50 \%$ RDF+VC 2.5 tha $^{-1}$ & $4.84^{\mathrm{abc}} \pm 0.21$ & $283.5^{b} \pm 2.7$ & $25.9^{\mathrm{a}} \pm 0.17$ & $138.0^{b} \pm 1.1$ & $2.5^{\mathrm{a}} \pm 0.12$ & $202.7^{\circ} \pm 2.7$ & $28.0^{c} \pm 1.5$ \\
\hline $50 \%$ RDF+ Lime $4 q_{\text {ha }}^{-1}$ & $4.80^{\mathrm{abc}} \pm 0.06$ & $228.8^{\mathrm{e}} \pm 3.2$ & $19.5^{b} \pm 0.98$ & $130.0^{\mathrm{d}} \pm 1.2$ & $2.3^{b} \pm 0.17$ & $184.7^{\mathrm{d}} \pm 2.8$ & $22.7^{\mathrm{d}} \pm 0.52$ \\
\hline $\begin{array}{l}50 \% \text { RDF+VC } 2.5 \text { tha }^{-1}+ \\
\text { Lime } 4 q \text { ha }^{-1}\end{array}$ & $4.95^{\mathrm{a}} \pm 0.22$ & $290.6^{\mathrm{a}} \pm 2.9$ & $27.2^{\mathrm{a}} \pm 1.7$ & $151.0^{\mathrm{a}} \pm 1.9$ & $2.5^{\mathrm{a}} \pm 0.06$ & $264.7^{\mathrm{a}} \pm 1.7$ & $44.7^{\mathrm{a}} \pm 0.64$ \\
\hline
\end{tabular}

Values within the same column followed by different letters $(a, b, c, d, e)$ are significantly different from each other at 0.05 level by Duncan Multiple Range Test(DMRT)

lime along with vermicompost which might have led to increase availability of nutrients and also improved microbial activity. Similar increase in yield components and yield of greengram was earlier reported by Rajkhowa et al. (2000). Karmegam et al. (1999) also reported that application of vermicompost significantly stimulates the growth and yield of greengram.

Combined application of $50 \%$ RDF with VC $\left(2.5\right.$ tha $\left.^{-1}\right)$ and lime $\left(4 q \mathrm{qa}^{-1}\right)$ resulted in significantly higher build up of available $\mathrm{N}, \mathrm{P}_{2} \mathrm{O}_{5}$ and $\mathrm{K}_{2} \mathrm{O}$ in soil after the harvest of crop followed by the treatment receiving 50\% RDF + VC $2.5 \mathrm{t} \mathrm{ha}^{-1}$ and RDF applied alone (Table 2). Such improvement in available nutrient status might be due to prolonged availability of nutrients from vermicompost and also due to enhance mineralization of native nutrients. Higher biological activity in soil following vermicompost and lime application might have also added in mineralization of soil nutrients. Available $\mathrm{P}_{2} \mathrm{O}_{5}$ in soil ranged from $13.8-27.2 \mathrm{~kg} \mathrm{ha}^{-1}$, highest value was recorded with the treatment receiving $50 \%$ RDF + VC $2.5 \mathrm{t} \mathrm{ha}^{-1}+$ lime $4 \mathrm{q} \mathrm{ha}^{-1}$ and was at par with the treatment that received $50 \% \mathrm{RDF}+\mathrm{VC} 2.5 \mathrm{tha}^{-1}$.

Vermicompost being rich in $\mathrm{P}(1.2 \%)$ might have added appreciable quantity of $\mathrm{P}$ besides addition through fertilizer, and also solubilized the native $P$ in the soil through release of various organic acids. Similar results were also reported earlier by Rajkhowa et al. (2003). Available $\mathrm{K}_{2} \mathrm{O}$ in soil also varied significantly due to nutrient management practices which ranged from $119.4-151 \mathrm{~kg} \mathrm{ha}^{-1}$ and followed the similar trend. These results corroborate the earlier findings of Karmakar et al. (2015). Vermicompost not only supplies the macro and micronutrients but also a store house of beneficial microorganisms. Application of vermicompost might have helped in better mineralization of native nutrients by creating better soil environment. Similar improvement in soil nutrient status following combined application of vermicompost and RDF was also been reported by many workers (Singh and Wasnik, 2013; Rajkhowa et al., 2000). Integrated use of $50 \%$ RDF + VC $2.5 \mathrm{t} \mathrm{ha}^{-1}+$ lime $4 \mathrm{q} \mathrm{ha}^{-1}$ also significantly improved the soil organic carbon $(2.5 \%)$ as compared to the treatment receiving fertilizer alone $(2.2 \%)$. Soil $\mathrm{pH}$ ranged from $4.70-4.95$, highest being with the treatment receiving integrated use of $50 \%$ RDF + VC 2.5 tha $^{-1}+$ lime $4 q_{\text {ha }}{ }^{-1}$. Increase in soil pH might be due to application of organic fertilizer and lime as it increases soil pH by supplying bases, forming alkaline humates during the process of decomposition. Increase soil pH following vermicompost application was also reported by Mathivanan et al. (2013).

The nutrient management practices exerted significant influence on build up of soil microbial population. Among different treatments, application of 50\% RDF + VC 2.5 t ha $^{-1}+$ lime $4 \mathrm{q} \mathrm{ha}^{-1}$ resulted in maximum bacterial $\left(264.7 \times 10^{6} \mathrm{~g}^{-1}\right)$ and fungal $(44.7 \mathrm{x}$ $10^{5} \mathrm{~g}^{-1}$ ) population followed by the treatment receiving $50 \%$ RDF + VC 2.5 (t ha $\left.{ }^{-1}\right)$; while lowest population was recorded in the treatment receiving only recommended dose of fertilizer (Table 2). Such improvement in soil microbial population might be due to adequate supply of nutrient and energy from applied vermicompost. Increase in the microbial population following vermicompostapplication in soil was also reported by Rajkhowa et al. (2015) and Mahanta et al. (2012). Positive effect of vermicompost on the soil microbial communities was also reported by Pathama and Sakthivel (2012). Similarly, Lazcanoa and Dominguez (2011) also reported that application of vermicompost enhance the soil biochemical and microbial properties, and thereby promoting the microbial growth.

From the above findings, it can be concluded that integrated use of vermicompost 2.5 tha $^{-1}$ with $50 \%$ recommended fertilizer and lime $4 \mathrm{q} \mathrm{ha}^{-1}$ is beneficial for realizing the higher productivity of greengram and improvement in soil health.

\section{Acknowledgment}

The authors are thankful to the Director, ICAR Research Complex for NEH Region, Umiam, 793103, Meghalaya, India for providing necessary facilities to conduct this research work. 


\section{References}

Bray, R.H. and L.T. Kurtz: Determination of total, organic and available forms of phosphorus in soils. Soil Sci., 59, 39-45 (1945).

Edwards, C.A. and I. Burrows: The potential of earthworm composts as plant growth media. In: Earthworms in Waste and Environmental Management (Eds.: C.A. Edwards and E. Neuhauser). SPB Academic Press, The Hague, The Netherlands, pp. 21-32 (1988).

Indian Fertilizer Scenario: Department of fertilizer, Ministry of chemical and fertilizers, Government of India (2010).

Jackson, M.L.: Soil Chemical Analysis. Prentice Hall of India Pvt. Ltd. New Delhi (1962).

Karmakar, S., M. Adhikary, A. Gangopadhyay and K. Brahmachari: Impact of vermicomposting in agricultural waste management visà-vis soil health care. J. Environ. Sci. Natur. Resour., 8, 99-104 (2015).

Karmakar, S., K. Brahmachari and A. Gangopadhyay: Studies on agricultural waste management through preparation and utilization of organic manures for maintaining soil quality. Afr. J. Agric. Res., 8, 6351-6358 (2013).

Karmegam, N., K. Alagumalai and T. Daniel: Effect of vermicompost on the growth and yield of greengram (Phaseolus aureus Roxb.). Trop. Agr., 76, 143-146 (1999).

Kusro, P.S., D.P. Singh, M.S. Paikra and D. Kumar: Effect of organic and inorganic additions on physicochemical propertiese in vertisol. AIJRFANS, 5, 51-53(2014).

Lazcanoa, C. and J. Dominguez: The use of vermicompost in sustainable Agriculture: Impact on plant growth and soil fertility. In: Soil Nutrients (Ed.: M. Miransari), Nova Science Publishers New York, pp. 1-23 (2011).

Mahanta, K., D.K. Jha, D.J. Rajkhowa and M. Kumar. Microbial enrichment of vermicompost prepared from different plant biomasses and their effect on rice (Oryza sativa L.) growth and soil fertility. Biol. Agric. Hort., 28, 241-250 (2012).

Mahanta, K., D.K. Jha, D.J. Rajkhowa and M. Kumar: Isolation and evaluation of native cellulose degrading microorganisms for efficient bioconversion of weed biomass and rice straw. J. Environ. Biol., 35, 721-725 (2014).

Makulec, G.: The role of Lumbricus rubellus Hoffm. In determining biotic and abiotic properties of peat soils. Pol. J. Ecol., 50, 301-339 (2002).

Mathivanan, S., R. Kalaikandhan, A.L.A. Chidambaram and P. Sundramoorthy: Effect of vermicompost on the growth and nutrient status in groundnut (Arachis hypogaea. L). Asian J. Plant Sci. Res., 3, 15-22 (2013).
Nazir, N., J.H. Mirza, N. Akhtar, R. Bajwa and G. Nasin: Some studies of thermophilic and thermotolerant fungi from Lahore, Pakistan. Mycopath., 5, 95-100 (2007).

Pathama, J. and N. Sakthivel: Microbial diversity of vermicompost bacterial that exhibit useful agricultural traits and waste management potential. SpringerPlus, 1, 26 (2012).

Rajkhowa, D.J. and M. Kumar: Biowaste utilization for improving health and productivity of acid soils in North-East India. Curr. Sci., 104, 11-12 (2013).

Rajkhowa, D.J., A.K. Gogoi, R. Kandali and K.M. Rajkhowa: Effect of vermicompost on greengram nutrition. J. Ind. Soc. Soil Sci., 48, 207-208 (2000).

Rajkhowa, D.J., M. Saikia and K.M. Rajkhowa: Effect of vermicompost and levels of fertilizer on greengram. Legume Res., 26, 63-65 (2003).

Rajkhowa, D.J., P.N. Bhattacharyya, A.K. Sarma and K. Mahanta: Diversity and distribution of earthworms in different soil habitats of Assam, North-East India, an Indo-Burma Biodiversity Hotspot. Proc. Natl. Acad. Sci., India, Sect. B Biol. Sci., 85, 389-396 (2015).

Rao, D.L.N.: Microbial diversity, soil health and sustainability. J. Indian Soc. Soil Sci., 55, 392-403 (2007).

Singh, M. and K. Wasnik: Effect of vermicompost and chemical fertilizer on growth, herb, oil yield, nutrient uptake, soil fertility, and oil quality of rosemary. Commun. Soil Sci. PlantAnal., 44, 2691-2700 (2013).

Singh, N.P., R.S. Sachan, P.C. Pandey and P.S. Bisth: Effect of a decade long terms fertilizer and manure application on soil fertility and productivity of rice-wheat system in mollisol. J. Indian Soc. Soil Sci., 47, 172-80 (1998).

Sinha, R.K., S. Heart, D. Valani and K. Chauhan: Vermiculture and sustainable agriculture. Am. Euras. J. Agric. Environ. Sci., 5, 1-55 (2009).

Subbiah B.V. and G.L. Asija: A rapid procedure for assessment of available nitrogen in soils. Curr. Sci., 25, 259-260 (1956).

Swarup, A. and R.H. Wanjari: Three decades of All India Coordinated Research Project on LTFEs to study changes in soil quality, crop productivity and sustainability IISS, Bhopal, pp. 59 (2000).

Tomati, U., A. Grappelli and E. Galli: The presence of growth regulators in earthworm-worked wastes. In: Proceeding of International symposium on Earthwarms (Eds.: A.M. Bonvicini Paglioi and P. Omodeo). Modena, Italy, pp. 423-436 (1987).

Waksman, S.A.: Principles of Soil Microbiology. William \& Wilkins Co., Batimore (1927).

Walkley, A. and I.A. Black: An examination of the Degtjareff method for determining soil organic matter and a proposed modification of the chromic acid titration method. Soil Sci., 37, 29-38 (1934). 